\title{
Conversion of Agricultural Land and the Threat of Food Sovereignty in the Perspective of Law and Democracy (Case Study in Bandungan and Ambarawa Indonesia)
}

\author{
Tirta Mulya Wira Pradana ${ }^{1 \mathrm{a}}$, Bagus Edi Prayogo ${ }^{1}$, Indah Mutiara Dewi ${ }^{1}$ \\ ${ }^{1}$ Faculty of Law, Universitas Negeri Semarang (UNNES), Indonesia \\ ${ }^{\mathrm{a}}$ Tirtamulya01@gmail.com
}

\begin{abstract}
The country of Indonesia is an agrarian country and an archipelagic country with a vast land area of $1,890,754 \mathrm{~km} 2$ based on the results of the Round Table Conference (KMB) and has the potential of numerous islands scattered throughout the archipelago with a total of approximately 17,500 according to the Hydrographic and Oceanography Center Navy (Pushidrosal). As a country that has a wealth of agriculture is so abundant and the population is ranked third in Asia and ranked fourth in the world. As time goes by the development of the economic system as well as the increasing number of population density, so the need for land for the sake of residence is higher. The clash between the interests of survival and eating can lead to the conversion of agricultural land. Transfer of land that does not pay attention to environmental aspect and humanitarian aspect cause serious threat to the nation of Indonesia in the future. This paper examines (1) Human rights violations against farmers (2) Protection of agricultural land due to the granting of uncontrolled transfer of uncontrolled agricultural land functions to food threats (3) alternative use of customary law-based agricultural dispute resolution.
\end{abstract}

Keyword—human right; farmers; permissions; land conversion

\section{INTRODUCTION}

Also known as an agrarian country, or much use in farming to live and work, Indonesia is very sensitive to agricultural lands. In addition, conditions favoring the State of Indonesia situated in the astronomical and equatorial zones and also have many types of forests such as tropical rainforests, as well as fertile land, making more and more agricultural land used for the fulfillment of daily living needs. Farms are usually used by many people around to grow crops and become their main income as farmers.

The reason why Indonesia is an agrarian country because most of the land in Indonesia is traversed by one third of the ocean from the whole area. It also passed a row of lush mountains. Why is it so fertile? Because the location of the country of Indonesia is in a tropical climate to make the weathering process that occurred in Indonesia occurred perfectly that makes the soil becomes fertile. Indonesia is also the world's largest archipelagic country as 17,508 islands, and with a land area of $1,922,570 \mathrm{~km}^{2}$. Indonesia is an agrarian country with vast land area and very diverse biodiversity. It is very possible to make Indonesia State as the largest agricultural country in the world. In an agrarian country like Indonesia, agriculture has an important contribution both to the economy and to the fulfillment of the basic needs of society, especially with the increasing number of people which means that the need for food is also increasing.[1]

In addition there is an additional role of the agricultural sector that is increasing the welfare of the people who are mostly now below the poverty line. Although most of Indonesia's population livelihood farming and a lot of land that can be used as agricultural land but currently Indonesia is still short. One reason is agricultural land that switches from agriculture to nonagricultural functions. This kind of phenomenon can certainly bring serious problems in the future, if not anticipated seriously and well from now on. Actually, various policies related to the problem of controlling the transfer of rice field functions have been made One of them is Law no. 41 of 2009 on Sustainable Agricultural Land Farm Protection Article 34 paragraph 1 which states "Every person who owns land rights that are designated as sustainable food crops shall be obliged to utilize land according to the allocation and prevent irrigation damage, maintain and improve soil fertility, prevent natural damage and preserve the environment ". However, until now the implementation has not been successfully realized optimally. This is partly due to the lack of data support and lack of adequate proactive attitudes toward the control of the agricultural land conversion.

Based on the above description the authors are interested to raise the title in research on agricultural land changes to socio-economic and legal in Kecamatan Ambarawa and more specifically in Kelurahan Pasekan 
and Bejalen Kelurahan with the title "Land Transfer and Food Threat in Democratic Perspective" tourist areas and housing are viewed from the perspective of democracy, democracy requires the ease of choosing and ready to accept with all its consequences, economic conditions, new livelihood of farmers, and food security village Bejalen Ambarawa village after the conversion of agricultural land into tourist areas and so on.

\section{LITERATURE REVIEW}

\section{A. Understanding Land Function Transfer}

One of the phenomena in land use is the conversion of land (conversion) land. This phenomenon arose in line with increasing demand and demand for land, both from the agricultural sector and from the nonagricultural sector due to population growth and development activities. Kustiawan, 1997 (in Valeriana Darwis, 2008) argues that the phenomenon of land conversion takes place due to the structural transformation of the economy and demographics, particularly in developing countries. Utomo (1992) defines land conversion or is commonly referred to as land conversion as a partial or total change of function the land from its original function (as planned) becomes another function that has a negative (problem) impact on the environment and the potential of the land itself. Land use change in terms of change / adjustment of allotment of use, caused by the factors that broadly cover the need to meet the needs of the growing population and increasing demands for a better quality of life. [2]

Land use transfer is usually associated with the process of regional development, it can even be said that land conversion is a consequence of regional development. Much of the land conversion takes place, indicating an imbalance in land tenure which is dominated by the capitalist side by pocketing a build permit issued by the government. Wibowo (1996) adds that land purchase actors are usually not local residents, resulting in the formation of clusters that are generally susceptible to land conversion processes. Land function is mostly for residential and public facilities development activities. Winoto (2005) argues that the most vulnerable agricultural land for conversion of function is rice field. This is due to:

1. Population density in rural areas that have agroecosystem dominant rice fields are generally much higher than agro-ecosystem of dry land, so the population pressure on the land as well higher.

2. Many rice fields are located adjacent to the area urban areas.

3. Due to the pattern of development in the past. Regional Infrastructure rice fields are generally better than dry-land area.

4. The development of infrastructure and facilities of settlements, industrial estates, and so forth tend to be rapid in flat-topped areas, where in areas with such topography (especially in Java) the agricultural ecosystem is dominant in rice fields.

\section{B. Human Rights View Against Environmental Sustainability Rights}

With regard to human rights to the environment, by placing the state as a bastion of human rights, in the management of natural resources and environment, the people should be placed as the main interests. The state fully acts as an instrument of management and policy organizers aimed at protecting and promoting human rights on the environment. On the basis of the above thought it is clear that respect for human rights over the environment becomes a very important and fundamental aspect because the environment has all the limitations, so the control over human behavior on the environment becomes absolute. The control is one of them through instruments, mechanisms, and policies, both at the local, national, and international levels,

In its development, the conception of human rights over the new environment was apparent at the time of the United Nations Conference on Environment and Human Affairs in Stockholm, Sweden, on 5-6 June 1972, which sparked the Stockholm Declaration. This conference is the starting point of the international community's awareness of the importance of environmental sustainability as a fundamental part of the fulfillment of human rights. In Principle 21 and Principle 11 of the Declaration on the Human Environment of the Stockholm Conference, states that the state has a sovereign right to exploit its natural wealth in accordance with its policy of safeguarding and preserving its environment. In such utilization the state is responsible for any activities that harm the environment or other areas of the country that are outside its national jurisdiction. [3] Related to the right to a good and healthy environment can be observed the provisions of Law no. 40 Year 2007 regarding Limited Liability Company, which in this law is also regulated on social and environmental responsibility. In Article 74, it is specifically affirmed that "Companies engaged in activities in the field and / or related to natural resources are obliged to carry out social and environmental responsibility". If viewed contextually, then the company is also burdened with social and environmental responsibility is a company whose purpose and activities to explore the natural resources. The form of social responsibility can vary, the most important is to "rescue" the natural resources that increasingly disturbed the balance. The government began to feel it as an urgent, considering the impact is related with the livelihood of the people. Rescue the natural resources among others can be in the form of reforestation of the environment, the search for alternative energy alternatives in addition to nature, research and technology to reduce the impact of environmental damage, and so forth.

\section{RESEARCH METHOD}

The method used in carrying out Conversion of Agricultural Land and the Threat of Food Sovereignty in the Perspective of Law and Democracy (Case Study in Bandungan and Ambarawa Indonesia. The complete research method, as follows 
Types of Research: this type of legal research uses a survey with the aim of research to take samples from a place by conducting research activities to obtain an assurance of information on the Agricultural Land Protection Research Program Due to the Granting of Permits to Transfer Agricultural Land Functions that Are Not Controlled against Food Threats Ambarawa Semarang City) which includes survey preparation, area survey in Bandungan, Ambarawa District, data processing and evaluation. The results of the application of this survey research are to get the truth about a problem over the function of agricultural land and will expose data from the object of research, and interpret and analyze it systematical. $\{4\}$

Observation Method: research methods carried out in this program by using the observation method by collecting data directly down in the field and by direct observation by taking data by looking at an area by observing directly to regional objects in close proximity to obtain data.

Interview Method: the research method used by using the interview method is carried out systematically and based on the research objectives to obtain information by asking the respondent directly by using a tool called the interview guide. As for the results of the interview can be recorded properly and the researcher has evidence of interviewing the informant, the tools used during the interview are as follows: (1) the notebook serves to record all conversations with the informant, (2) tape recorder serves to record all conversations, and (3) the camera serves to photograph researchers at the time of the interview so that it can be used as research evidence

Data Collection Methods and Techniques: data collection methods and techniques used in this study are primary data collection methods in the form of field observations (surveys) which consist of a survey of identification of Bandungan area, survey of quantity and quality of functions of agricultural land, survey of diversity of land functions, and obtaining appropriate information from resource persons. trusted (interview). This study requires two types of data, namely as follows:

a. Primary data

Primary data is data that is obtained directly from the main sources that are in the form of views, thoughts, aspirations, actions, events, legal relations, and words. This type of data provides information or information directly about everything related to the object of research. This type of data is obtained directly in the field in the form of words or actions obtained through in-depth interviews, for which a structured interview relationship is developed by giving questions that show concern, guarding, cooperation that ultimately informants participate to provide valid information .

b. Secondary data

Secondary data is data obtained from literature, which includes three legal materials, namely primary, secondary and tertiary legal materials.

a) Primary legal materials are materials that have a legally binding power. Primary materials in the study include:
- Law Number 32 of 2009 concerning Environmental Protection and Management.

- Law Number 56 Prp of 1960 concerning Establishment of Agricultural Land Area

- Law Number 7 of 1996 concerning Food;

- Law Number 25 of 2004 concerning the National Development Planning System

- Act Number 4 of 2006 concerning Ratification of Agreement concerning Plant Genetic Resources for Food and Agriculture (International Treaty on Plant Genetic Resources for Food and Agriculture).

b) Secondary legal material is data obtained from literature. Secondary legal materials in this study include literature, journals, books, papers, internet, research reports and so on which are interrelated.

c) Tertiary legal materials or supporting legal materials to provide an explanation of primary legal materials and secondary legal materials. The tertiary legal material in this study includes, among others: Dictionary, Law, and Encyclopedia.

Data Analysis: data analysis in this study uses qualitative data analysts. Qualitative methods include research procedures that produce descriptive data in the form of written words or from oral explanations of people who are the object of the interview

\section{RESULT AND DISCUSSION} V.

\section{A. Essence of Legal Policy for Land Function Transfer}

In the Spatial Perspective Legislation is very important and cannot be ignored, especially in a legal state. As is known that one elements of the rule of law are governments based on laws and regulations or what is often referred to as the principle of legality, the principle of legality is one of the main principles that is used as the basis for every administration and state in every legal state. This legality principle will support the validity of legal certainty, because legal certainty will occur because regulations can make any actions that will be carried out by the government can be predicted or estimated by looking at the applicable laws, then the principle can then be seen or what government officials are expected to do is expected. The law in Indonesia must be aimed at achieving the goals of the State as stated in the opening of the 1945 Constitution, namely to build all nations and all of Indonesia's bloodshed, educate the life of the nation, promote prosperity and people's lives. [5] The constitutional provisions must be used as a political instrument of development and legal politics to restructure national agrarian politics within the framework of agrarian reform by making Pancasila a paradigm of legal politics, so that Pancasila can function as a philosophical philosophy and common flat forms in the context of state life one of the most popular spatial utilization control instruments is licensing. Licensing instruments control every spatial utilization activity in accordance with the spatial plan that has been set. Thus to find out whether the use of space has been in accordance with its designation can be seen from the legislation in the spatial planning 
field. Related to this, to find out whether permits can be issued to businesses to change the function of plantation land into tourist areas in protected areas, it is necessary to examine the suitability between the planned use of protected areas

\section{B. Mechanism Determination Requirements Transfer of Land Functions}

1. The nature of licensing

Permits are the most commonly used state administrative law instruments the government in controlling the behavior of its citizens. Permits are considered to be able to control every business and / or activity that has the potential to cause pollution and damage environment, this is based on the essence of the permit itself which prohibits a certain person or legal entity from carrying out an activity and / or business without obtaining prior approval / approval from the authorized state administration body or official. The permit has a preventive function because the permit instrument cannot be separated from the orders and obligations that must be obeyed by the permit holder. This also applies to people or business entities that will conduct tourism businesses or establish building and so on.[6]

2. Mechanism of Licensing for Land Function Transfer In connection with this matter, the licensing mechanism will be described in the permit application for land use transfer for tourism activities regulated in the Regulation on the Regulation How to Permit a Location in Semarang Regency, the licensing mechanism are as follows:

a. The application for a permit to provide tourism facilities is submitted by the applicant to the regent

b. The regent in accordance with his authority based on the request evaluates the requirements. In the event that the application submitted is not in accordance with the requirements, the regent in accordance with his authority returns the application to the applicant.

c. In the event that the application referred to above has met the requirements, the regent in accordance with his authority gives principle approval for the business of providing tourism facilities to the applicant.

d. Principal approval as referred to above is granted for a maximum period of 1 (one) year since the regent is issued in accordance with his authority.

e. Applications for tourism concession permits must be completed with administrative and technical requirements.

Factors Affecting the Transfer of Land Functions and Their Impacts in Bandungan and Ambarawa Regency. [7]:

1. Factors that Influence the Transfer of Plantation Land Functions to become Tourism Areas In the event that the conversion of plantation land becomes a tourism area, there are several factors that encourage the occurrence of this, among others.

a. a. The high interest in land to be used as a tourism area so that people are tempted to sell their land. b. Land requirements for business activities between real estate development, industry, trade zones and other services require a large area, some of which come from plantation land, agriculture.

c. Environmental degradation, among others, long droughts that cause water shortages creates a problem for the community.

d. Regional autonomy that prioritizes development in the sector promises higher short-term profits to increase Regional Original Revenue (PAD), which is lackingpay attention to the long-term interests and national interests that are actually important for society as a whole.

e. Weak legal system and law enforcement (Law Enforcement) of existing regulations.

The results achieved certainly follow the use of this program aimed at several parties, namely [8]:

1. For The Government

- The Indonesian government will know about the dangers of land conversion to sustainable food threats in Indonesia.

- The Indonesian government is expected to prevent and get relief solutions to the food crisis that threatens Indonesia.

- The results of this study are expected to be taken into consideration in the issuance of policies and regulations related to the transfer of land functions that occur, as well as having a solution to solve the problems of land conversion that occur in Indonesia at present and in the future.

2. For the community

- The public will be able to be more careful by those who are not responsible for the transfer of agricultural land functions.

- The public can find out the dangers of land conversion to the threat of a food crisis for Indonesia.

\section{Home of Justice Pro Farmers Modern Design Implementation Techniques}

In order for Home Of Justice Pro Farmers Modern Design to be implemented, cooperation is needed between the parties, namely the government as the executor, students as the idea makers, and the related parties. The Department of Agriculture, the Environment Agency (BLH), the Institute of Sciences, and the government coordinate with real regulations. [9] With the existence of the regulation, this concept will be integrated and so that agriculture and farmers will create modern Indonesian agriculture which will generate agriculture, especially in food.

In order to achieve this program, it will be carried out in several stages that have been designed and planned with methods of data collection regarding land conversion, urban spatial planning, and food sovereignty from the Semarang City Agriculture Service, Semarang City Regional Development Planning Agency, National Defense Agency Semarang city. Then by using survey research methods to take samples from a place or citizen 
from the Bandungan Ambarawa place to obtain information certainty in the Agricultural Land Protection Research Program that is Uncontrolled against Food Threats (Case Study of Ambarawa Bandungan, Semarang Regency). [10] Data collection is done to obtain information needed in order to achieve the research objectives.

\section{CONCLUSION}

From the results of research in Ambarawa sub-district, Pasekan and Bejalen sub-districts, there is a change of society pattern which tend to be modernist, leaving the agriculture, due to the people who are reluctant to go to agriculture, so land conversion function occurs, but now with the regulation no 6/2011 permission to change the land function is tightened, thus changing the community order which was formerly build first and then the permit, then vice versa

\section{REFERENCES}

[1] Rachmad K. Dwi Susila. (2013). Sosiologi Lingkungan Jakarta. Rajawali Pers, p.89-104,

[2] Rahayu. (2015). Hukum Hak Asasi Manusia. Badan Penerbit Universitas Diponegoro, p.215

[3] Riant, Nugroho. (2012). Public Policy: Dinamika Kebijakan, Analisis Kebijakan, Manajemen Kebijakan. Elex Media Komput indo, p. 108-146

[4] [Sugiyono. (2013). Memahami Penelitian Kualitatif. Alfabeta, p. 79-101.

[5] Utomo, M., Eddy Rifai dan Abdulmutalib Thahir. (1992). Pembangunan dan Alih Fungsi Lahan.Lampung. Universitas Lampung. P. 80-109.

[6] Abubakar, Lesturi. (2013). Revitalisasi Hukum Adat Sebagai Sumber Hukum Dalam Membangun Sistem Hukum Indonesia. Jurnal Dinamika Hukum. P. 320-328

[7] Agung Arifianto, Harry. (2016). Penerapan Sanksi Administrasi Akibat Pencemaran Lingkungan Hidup (Studi Kasus di C V Slamet Widodo Semarang. Unnes Law Journal, p.25

[8] Dewi, dkk. (2015). Faktor-Faktor Pendorong Alihfungsi Lahan Sawah Menjadi Lahan Non-Pertanian (Kasus: Subak Kerdung, Kecamatan Denpasar Selatan). Jurnal Manajemen Agribisnis. 163-169

[9] Faiz, Mohamad Pan. (2016). Environmental Protection in Constitutional Perspective. Jurnal Konstitusi, p, 767-781.

[10] Setiawan, Handoko Probo. (2016). Alih Fungsi (Konversi) Lahan Pertanian Ke Non Pertanian Kasus Di Kelurahan Simpang Pasir Kecamatan Palaran Kota Samarinda. eJournal Sosiatri-Sosiologi, 280-285 